\title{
ROGER CASEMENT IN THE TWENTY-FIRST CENTURY: THE PUBLIC AND PRIVATE FACES OF A MULTI-MEDIA IRISH HERO
}

\author{
Domingos Nunez ${ }^{1^{*}}$ \\ Peter James Harris ${ }^{1 * *}$ \\ ${ }^{1}$ Universidade Estadual de São Paulo, São José do Rio Preto, SP, Brasil
}

\begin{abstract}
Sir Roger Casement (1864-1916) was a diplomat in the British Colonial Service and an Irish nationalist who was hanged for high treason in London in 1916. The first part of this article offers a critical overview of the material that has been published about Casement's humanitarian work in the Congo and the Peruvian Amazon and his trial in London, including biographies and editions of his own journals, particularly the so-called Black Diaries, as well as the various dramatisations of this material for the stage and other media, concentrating on those produced in the twenty-first century. The second part of the article consists of the playwright's first-person account of the writing of As Duas Mortes de Roger Casement (subsequently translated into English as The Two Deaths of Roger Casement), which received its premiere in São Paulo in 2016, commenting on the play's relationship to its sources and the decisions that were taken in the creative process.
\end{abstract}

Keywords: Sir Roger Casement; Putumayo; Black Diaries; Dramatisation; Homosexuality.

\footnotetext{
"Has a PhD in Irish Studies from the University of São Paulo and National University of Ireland Maynooth (2005); and a post-doctorate from the State University of São Paulo, São José do Rio Preto (2017). He is a translator, playwright and Artistic Director of Cia Ludens, a professional theatre company based in São Paulo whose main purpose is to translate, publish and produce Irish plays in Brazil. Author and director of The Two Deaths of Roger Casement (2016), Nunez has also translated and directed five other plays for Cia Ludens. In addition to academic articles on Cia Ludens creative processes, Nunez has also published a volume with four short plays by Bernard Shaw (Musa, 2009) and a box containing four plays by Brian Friel (Hedra, 2013), and four plays by Tom Murphy (Iluminuras 2019). Email: domingosnunez@bol.com.br. ORCID: 0000-0002-7067-1817

" Professor of English Literature at the State University of São Paulo (UNESP), São José do Rio Preto. Born in London he has a Ph.D. in Irish Studies from the University of São Paulo. In 2006, he completed his PostDoctorate at the Drama and Theatre Department of Royal Holloway University of London, where he was Visiting Research Fellow. He is the author of Sean O'Casey's Letters and Autobiographies: Reflections of a Radical Ambivalence (WVT, 2004), From Stage to Page: Critical Reception of Irish Plays the London Theatre, 1925-1996 (Peter Lang, 2011) and A Peça Irlandesa no Palco Londrino (Humanitas, 2011), in addition to chapters and articles on twentieth-century Irish dramatists, including contributions to Christopher Murray's Alive in Time: The Enduring Drama of Tom Murphy (Carysfort Press, 2010) and Donald E. Morse's Irish Theatre in Transition: From the Late Nineteenth to the Early Twenty-First Century (Palgrave Macmillan, 2015). Email: peter.harris@ unesp.br. ORCID: 0000-0003-2399-5963
} 
Sir Roger Casement is one of the most controversial individuals to have participated in the struggle for the independence of Ireland. Since his execution in August 1916, he has received various biographies, and his social legacy and disputed sexual behaviour have been the subject of endless academic interest. Edited and recreated, this material has been adapted to create literary works. In the second half of the twentieth century, some attempts were made to reimagine Casement in fictional contexts, but it has been only in the last few years that his story has attracted so much attention. It is surely no coincidence that 2016 - the centenary of the Easter Rising, the failed insurrection that resulted in Casement's trial and hanging - brought a flood of new recreations of his life.

The present article begins by examining choices made by some of the twenty-first-century writers who have produced theatre, radio and cinema dramatisations of Casement's public and private life. In the second part, Domingos Nunez (2017), writing as a Brazilian dramatist and theatre director, gives a firstperson account of his own artistic decisions in writing and producing As Duas Mortes de Roger Casement. The play was developed from 2013 to 2017 during a four-year postdoctorate at UNESP (São Paulo State University), São José do Rio Preto, under the supervision of Professor Peter James Harris, the first academic to publish on Roger Casement in Brazil. (The play was translated into English under the title The Two Deaths of Roger Casement, performed at NUI Galway in 2018 and published by Bloomsbury in 2020.)

Any writer on Casement is inevitably dependent upon the journals, letters, reports and poems written by Casement himself, as well as biographies and other writings by various academics. The first biography was René MacColl's Roger Casement: A New Judgement (1956), published when witnesses were still alive, many of whom were interviewed by the author, including Sergeant Sullivan, the counsel for Casement's defence. Just three years later Peter Singleton-Gates and Maurice Girodias (1959) published The Black Diaries - an account of Roger Casement's life and times, with a collection of his diaries and public writings, the first book to contain the 1903 and 1910 Black Diaries and Casement's partial official reports to the Foreign Office covering the same year. The British authorities had prevented the authors from publishing their book in Great Britain when they first tried to do so in 1925, and it was not printed until 1959, when it was published in Paris, outside British jurisdiction. More than a decade then elapsed before the appearance of Brian Inglis's (2002) Roger Casement (1973), a chronological account concentrating on the African, Irish and First World War aspects of Casement's biography, but which pays scant attention to his activities in South America. In 1976, B. L. Reid added The Lives of Roger Casement, a thoroughly researched biography with a particular focus on the German episode of 1914-16.

The most significant publications in the 1980s were Roger Sawyer's The Flawed Hero (1984), the first biography of Casement to deal at any length with his family background and upbringing; and his Roger Casement's Diaries - 1910: The Black and the White (1984), a volume containing the 1910 Black Diary unabridged and extensively annotated, alongside an abridged version of Casement's 1910 Amazon 
Journal. The complete version of this Journal was only published in 1997, edited by Angus Mitchell as The Amazon Journal of Roger Casement. Angus Mitchell (1997) is also the author of a biography - 16 Lives: Roger Casement (2013), which recognises Casement's importance as a human rights activist, but expresses scepticism about the authenticity of the Black Diaries. In 2003 Mitchell published The 1911 Documents, containing Casement's official reports and correspondence for that year. This latter publication serves as a kind of counter-argument to Jeffrey Dudgeon's The Black Diaries (2002) - which features Casement's complete 1911 Black Diary, for the first time in print, an abridged version of the 1903 Black Diary and another annotated version of the 1910 Black Diary. In 2016, Dudgeon's (2016) Roger Casement's German Diary 1914-1916, expanded Charles Curry's original 1922 edition of Sir Roger Casement's Diaries - His Mission in Germany and the Findlay Affair, which contains the diaries covering Casement's time in Germany. An unabridged and carefully corrected and annotated version of the 1903 Black Diary and The Congo Report of that year was edited by Séamas Ó Síocháin and Michael O'Sullivan, in 2004, entitled The Eyes of Another Race. Ó Síocháin's biography, Roger Casement: Imperialist, Rebel, Revolutionary (2008), is similarly focused on Casement's activities in Africa, though without detriment to his work in South America, Ireland and Germany.

Another very important source, used by almost everyone who has reimagined Casement dramatically, is The Trial of Roger Casement (1960), edited by Harford Montgomery Hyde (1973). This publication contains the transcripts of Casement's trial at the High Court of Justice, in London, from 26 to 29 June 1916; and the proceedings in the Court of Criminal Appeal between 17 and 19 July 1916. It is introduced by the author, who gives a detailed account of Casement's movements from his arrest on 21 April 1916 in the Bay of Tralee on the south-west coast of Ireland, to his execution at Pentonville prison, in London. Also worth mentioning is Herbert O. Mackey's (2003) The Crime against Europe - The Writings and Poetry of Roger Casement (1958), containing a collection of Casement's articles, some of his letters to newspapers, and fifty-one of his poems. Some of these writings were republished in 2003 by Brendan Clifford as Roger Casement: The Crime Against Europe with The Crime Against Ireland, and other writings.

Most of these researchers have also published academic articles on Casement, adding to the voices of other outstanding scholars and artists who have contributed to the debate on Casement's legacy. These include Lucy McDiarmid, with her seminal essay "The Posthumous Life of Roger Casement" (1997), and the poet Colm Toíbín, with his "A Whale of a Time" (1997), a long review of that year's simultaneous publications of the 1910 Black Diary, edited respectively by Roger Sawyer and Angus Mitchell. Brazilian academic literature extends from Peter James Harris's "From the Putumayo to Connemara: Roger Casement's Amazon Voyage of Discovery" (2002) to Mariana Bolfarine's (2016) "From Fragments to a Whole: Homosexuality and Partition in Cries from Casement as his Bones are Brought to Dublin, by David Rudkin" (1974), as well as Between "Angels and Demons": Trauma in Fictional Representations of Roger Casement (Bolfarine 2018), a book- 
length study by the same author. An issue faced by almost all the above writers is the question of whether the so-called Black Diaries, containing descriptions of Casement's sexual encounters with young men, are genuine or forged.

This question is also central to the majority of the dramatic works to be considered here. The novelist John Banville, the first writer this century to dramatise Roger Casement's legacy, wrote the screenplay Casement, in 2001, for the Irish filmmaker Neil Jordan. Although the film was never made, the script was published in Breac - A Digital Journal of Irish Studies, in April 2016. In a fictional dialogue in the opening sequence of the screenplay between the historical characters Sir Ernley Blackwell, legal adviser to the Home Office, and G. M. Mair, one of the principal officers of the British Ministry of Information, Blackwell seems to accept the Black Diaries as genuine, although he argues that "they do not show sufficiently clearly just how depraved and rapacious [Casement] is" (5). So Blackwell suggests that the officer should hire a master forger to interpolate "recollections of sexual excesses in the diary of Armando Normand, the Peruvian gauleiter and Putumayo section chief" (Dudgeon 538), whom Casement tried to indict for crimes perpetrated in the Upper Amazon basin. Banville (2016) appears to defend the once popular but long-abandoned thesis that "the pornographic material was derived from a diary kept by [Normand]" (Sawyer 17). There are serious doubts about the veracity of Normand's diary and, indeed, its very existence is doubtful. Even so, the forgery of Casement's diaries, or parts of them, is the central narrative thread in Banville's screenplay, and he is so attracted by the potential dramatic effects of his choice that he even introduces a fictional novelist, who is paid by the likewise fictional master forger to lend even more credibility to the material. Within this plot, which takes places in 1916, at the time of the trial, when pages of the so-called Black Diaries started circulating, Banville intersperses episodes of Casement's career and love affairs from 1909 until his execution at Pentonville prison.

Banville rarely paraphrases the bibliographical material researched, and most of the scenes depicted are fictionalised situations inspired by the biographies of Casement and those around him, with the exception of some rent boys who cannot be recognised among those mentioned in the diaries. Nonetheless, his references, taken mainly from the Amazon Journal, the German diary and the Black Diaries, are evident throughout his narrative. Possibly due to the similarities between the Congo and the Putumayo investigations, the vast material concerning Casement's movements in Africa from the late 1880s to 1903, and later in Ireland up to 1909, features little in Banville's script, beyond a few retrospective remarks.

The Roger Casement that emerges from Banville's screenplay is a paradoxical character: the public man is idealistic in his work as a defender of human rights, but also realistic in his assessment of the 1916 Easter Rising; while the private man is an adult male at ease with his sexual preferences, vaguely revealed to his sister Nina, who approves of his behaviour and occasionally affected manners.

In The Dreaming of Roger Casement Patrick Mason (2016) starts from a similar premise to Banville's, so far as the Black Diaries and Casement's private life are concerned. Written as a radio play for RTÈ Radio 1 in 2012, it was made 
into a stage-play in 2013, which was first presented in a reading by the author on 26 October that same year during the conference Roger Casement (1864-1916): the Global Imperative, hosted in Tralee by the Universities of Notre Dame and Limerick. A revised version of the play was also published in Breac - A Digital Journal of Irish Studies, in April 2016.

Central to both Banville's and Mason's narratives are the characters linked to Casement's trial and execution. In Banville's version, Sir Ernley Blackwell is an isolated schemer working to destroy Casement's reputation, while in Mason's play he is part of a team with that same purpose, together with F. E. Smith, the Attorney General, Counsel for the Crown during the trial, and Basil Thomson, Head of the Special Branch of Scotland Yard. Smith and Thomson are both in Banville's screenplay, but their roles are closer to their actual participation in Casement's arrest and trial than those in Mason's version. Mason does not agree with the forgery theory and, accepting the Black Diaries to be genuine, he restricts his plot to the year 1916, when Casement was seized on Banna Strand and taken to London to be tried. The playwright is chiefly interested in speculating how the Black Diaries ended up at Scotland Yard and were used by those in power to blacken Casement's name.

The fictional scenes involving this trio of conspirators drive Mason's narrative, to the exclusion of almost all else. Some passages from the Black Diaries are read aloud by two fictional copyists involved in transcribing them, while Casement appears briefly in the prisons where he was held, haunted by the ghost of an old Unionist aunt, commenting about his diaries and public interventions, and reflecting upon his struggle to set Ireland free from the English yoke.

Mason's Casement is visited in his Pentonville cell by his devoted cousin Gertrude Bannister, who did indeed visit him in prison - but the way they openly discuss his private sexual life, after she insists that Blackwell show her the Black Diaries, has no connection with the historical nature of their relationship. In Mason's version, Casement stands firm, "calm . . . and at peace" (45) with his sexuality, and Gertrude, like Nina in Banville's screenplay, not only accepts his sexual preferences, "however strange, however hurtful," but also insists that he should send a message to Millar Gordon, whose name is mentioned several times in the Black Diaries, and whom he appears to have loved. At the end of the play, Gertrude tells her conscience that "the diaries are ... government forgeries" and what should be remembered about Casement is that he "laid down his life for [Ireland]" (49). This final utterance seems to be much more in accordance with what the real Gertrude's opinions.

Mike O'Donnell's Roger Casement's 1916 (2013) is also set in 1916, but O'Donnell has no interest in the controversy surrounding the Black Diaries. His verse drama focuses on the public events of Casement's life from his capture up until his execution. Based on the facts in the official documents, O'Donnell's intention is to describe the hero's trajectory from the sands of Banna Strand to the steps of the English gallows. However, in a coda, he also inserts episodes detailing Casement's exhumation from the quicklimed soil of the Pentonville 
prison yard and the re-interment of his remains in Dublin's Glasnevin Cemetery in 1965. The existence of the Black Diaries and "the mere possibility of Casement's homosexuality" (30) are mentioned briefly as part of the campaign to tarnish Casement's name. The campaign is reduced to two fictional visits a Police Detective pays to Sir Arthur Conan Doyle, one of the many supporters who contributed to Casement's defence costs and to whom the compromising diaries were shown. After analysing the material Doyle states that "whether the author was my dear friend/ Or the work of a fraudster with a skilled hand,/ Such material matters much/ Only to the minds of the idle curious" (30). But, despite invoking Doyle's fictional opinion that Casement's public life is what really matters, O'Donnell acknowledges that support for the reprieve campaign waned after the diaries appeared and, as a result, the British Government felt more comfortable about having Casement executed.

In a note to directors, O'Donnell describes Roger Casement's 1916 as "a play" that can be "performed as either a one-man show or otherwise" (2); however, it has more in common with an epic poem than a dramatic monologue. It is thus unsurprising that it has yet to be staged since its publication in a Kindle edition on 11 April 2013. The work consists of almost 2,000 lines, divided into thirtythree episodes, each with its own descriptive title. The narrator is a contemporary of Casement, Lindsey Talbot Crosbie (1844-1913), an Irish landlord of moderate views who, in 1902, wrote to the press calling for a settlement between the respective interests of landlords and tenants. He hoped that a landlord-tenant conference might encounter a solution for the land question. In O'Donnell's play, Talbot Crosbie is an almost omniscient and omnipresent narrator at times perceived by other characters and at others invisible to them. He dogs Casement's footsteps, as well as talking to him, ghost-like, in the middle of public sessions without anyone hearing them.

O'Donnell's choice of such a narrator probably derives from the fact that both Talbot Crosbie and Casement campaigned to unite Catholics and Protestants. Both men believed that progress should begin with the coming together of moderate men of different parties. In letters to the press, Talbot Crosbie constantly tried to persuade Unionists to abandon their views on land ownership and welcome a new order. However, there are no records that the two men ever met, and Talbot Crosbie does not feature in any material written by or about Casement. Even so, the fervent involvement of the two men with their respective causes seems to explain why these two characters who never had any sort of contact were thrown together in O'Donnell's poem/play. Notwithstanding the fictional link between the two men posited by O'Donnell, he cannot hide the gulf of difference between them: whereas Casement died in furtherance of the Irish War of Independence, Talbot Crosbie, as imagined by O'Donnell, stands out merely for his refusal to deny Casement's achievements.

Devised as a documentary radio play, Roger Casement's 'Apocalypse Now', written by Colin Murphy (2016), in association with Ronan Kelly, was broadcast by RTÈ Radio 1 on 25 March 2016, as part of "a series of documentaries on the 
centenary of the [Easter Rising]" (Murphy 1). In this particular work, Murphy, the author of many other documentary plays, takes the role of narrator himself, travelling to Banna Strand and from there to Belfast, in the company of the historian and Casement scholar Margaret O'Callaghan, with the purpose of interviewing some people connected to Casement, the dead patriot "every person of [his] generation in Ireland and older, grew up with some sense of," but about whom they knew little more than that he was "the guy with the diaries" (3). The travellers first meet Patrick Casement, one of Sir Roger's surviving relatives, who talks about the family's history, as well as curiosities about some of Casement's personal belongings which still remain in the house of his youth.

Snippets of this conversation provide Murphy with material which he expands and incorporates into his brief comments about Casement in the Amazon and Germany, and his trial and execution, but which feature principally in the extensive narrative of Casement's movements and achievements in Africa. Murphy quotes directly from Casement's private and consular correspondence of that period, the Congo Report and the 1903 diary; and, since Africa is the focus of his play, he makes frequent reference to the documents edited by Séamas Ó Síocháin and Michael O'Sullivan in The Eyes of Another Race.

Murphy places at the centre of his play the casual meeting between Casement and Joseph Conrad in the Upper Congo in the early 1890s and digresses about the influence that Casement might have had on a book that Conrad later wrote, inspired by his African experience. Paraphrasing the story related in some of the biographies, Murphy narrates how "Casement would have told Conrad a story about an earlier journey that he took up the river Congo" during which he met a Captain who "told him that he paid his cannibal soldiers five brass rods per human head they brought" (Murphy 13). This story supposedly formed the basis for Conrad's (1989) short novel Heart of Darkness (1902), which in turn inspired Francis Ford Coppola’s film Apocalypse Now (1979), “in which Marlon Brando plays a renegade American officer, in Vietnam, called Kurtz" (13), the same name as one of Conrad's protagonists.

Murphy's apocalypse analogy implies a connection between the sufferings of the different characters in the forest and, in Casement's case, the harm the Black Diaries did in his life. By way of corroboration, in addition to quotations taken from undisputed documents, Murphy cites a couple of lines from the erotic references in the 1903 Black Diary. The diary for this year - basically a window onto Casement's consular life that provides "glimpses of the details" (Ó'Síocháin 20) of his professional and private activities, with some "evidence for his sexual orientation and habits" (25) - together with the other two Black Diaries, is the object of the discussion with Jeffrey Dudgeon, another of the interviewees Murphy and his travelling companion talk to in Belfast. The fact that Dudgeon has edited the Black Diaries and has written extensively about them, besides being a gay activist in Northern Ireland, is a clear indication of the playwright's standpoint on the authenticity of the Black Diaries. The play reveals the narrator's fascination with "Casement's contradictions" and the confidence with which "a ferociously 
masculine man expressed himself in gay ways" (Murphy 2), an opinion conveyed by one of his interlocutors at the very beginning of the play.

Also written in 2016, The Dream of the Celt, a play not yet published or produced, by the award-winning documentary filmmaker Alan Gilsenan, is an adaptation of the eponymous 2010 novel by the Peruvian Nobel Prize laureate Mario Vargas Llosa. Gilsenan, who was also scriptwriter and director of the 2002 documentary, The Ghost of Roger Casement, among many other films, lends a cinematic touch to his play-script when he expects, for instance, that, at a given moment, "snow [falls] across the stage" (21) and "clouds of the fine dust catch the light" (47). Predominantly, however, theatrical devices are put to work in this transposition for the stage of the semi-fictional biography of Casement as conceived by Llosa in his long narrative. For obvious reasons, the Peruvian novelist focuses on Casement's voyages to the Peruvian Amazon, where he investigated atrocities among Putumayo rubber gatherers, rather than his movements in Africa, Germany and Ireland.

In his two-act adaptation, Gilsenan loosely reproduces some episodes from Llosa's plot, and also creates new scenes that are not in Llosa's narrative. Just as in the central structure of the novel, Gilsenan depicts Casement in Pentonville prison awaiting his execution, in 1916, watched by the character referred to in the English translation of the novel as the Sheriff. In the meantime, just as in Llosa's novel, Casement chronologically recalls his career on three continents and gradually becomes fond of the Sheriff when he understands that the reason why the prison officer does not like him is that he had a very young son who was killed fighting for England in the war. All the characters in both the novel and the play are historical figures, recognisable in the sources, with the exception of this fictional Sheriff, created by Llosa and adapted for the stage by Gilsenan. The subtle difference is that, while the novelist divides his attention equally between other characters drawn from Casement's public and private life, Gilsenan chooses to focus on Casement's public relationships, and the issue of his homosexuality and promiscuous encounters fades away into vague suggestions dispersed throughout the play. The few scenes in which Casement's sexuality is in evidence consist of his hypothetical romantic meetings with Adler Christensen, the Norwegian sailor he hired in New York to go with him to Berlin "as his 'servant"' (Inglis 271), to whom he declares his unconditional love and is reciprocated - a complete artistic license so far as historical data can be verified.

Both the novelist and the playwright seem to accept that the Black Diaries are genuine, although Gilsenan completely disregards the thesis defended by Vargas Llosa that Casement did not experience most of the sexual encounters recorded in the diaries. For Vargas Llosa, Casement wished he had had them and therefore made up obscene, improbable situations and jotted them down in diaries, alongside those more puerile experiences in which he truly took part. This is a notion that was first broached by Roger Sawyer (1997) in his Introduction to Roger Casement's Diaries 1910: The Black and the White, where he states that "the obsessive quality of the erotic details has alienated many. Perhaps some of it is 
fantasy ... "(3). Gilsenan apparently feels as uncomfortable as Llosa with regard to the infamous Black Diaries.

One of the two stage plays on Casement so far produced, the as yet unpublished MacKenna's Fort, by Arnold Thomas Fanning, premiered at the New Theatre, Temple Bar, in Dublin, on 21 March 2016 and was subsequently staged, in May, at The Teachers' Club, during the 13th International Dublin Gay Theatre Festival. This play for one actor, directed by Paul Kennedy and featuring Michael Bates as Casement, won the Gay Theatre Festival and the Oscar Wilde Award for Best New Writing. In the historical situation reimagined by the playwright, Casement is placed in Mackenna's Fort, a circular stone ruin surrounded by a trench, in April 1916, on the eve of the Dublin Easter Rising. Together with Robert Monteith - "a former officer in the Irish Volunteers, sent ... to Germany to help train the Irish Brigade" (Inglis 304), and Julian Bailey, "a roguish young sergeant of the Brigade" (Reid 341), Casement was put ashore in Tralee Bay by a German U-boat, at the end of a dreadful voyage from Germany with the purpose of persuading the leaders to call off the rising. Debilitated by malaria, he was taken to the fort and left there waiting for his companions to come back with help to take him away to a safer place.

In Fanning's play, while he waits in the fort, as the night progresses, Casement recollects some of his experiences as British consul in Africa and South America. These include: in Belgian Africa, the shocking case of the young boy, Epondo, who had his left hand cut off by a local agent who was forcing him to harvest rubber (an episode related in the Congo Report Enclosures, edited by Ó Síocháin and O'Sullivan), and the meeting with Joseph Conrad; and, in the Amazon region, the story of Katenere, "the brave chieftain of the Boras tribe . . . who tried to fight back" (Fanning 23) against the Peruvian Amazon Company, which was exploiting the natives and killing those who refused to gather rubber, the Indian with whom "Casement came to sympathise and identify" (Mitchell 231). The playwright does not highlight Casement's interventions either in Germany or in Ireland. The reason for this is that he is more interested in achieving a tight connection between the Irish patriot's public life and his private sexual encounters, as revealed by the Black Diaries, from which Fanning (2016) quotes and recreates many episodes.

When his mind returns once again to Mackenna's Fort, Casement reflects upon his submarine voyage back to Ireland and the importance of his mission. In Fanning's version, Casement attaches no importance to the fact that he risks being accused of high treason by the British authorities. What really matters is his optimism about the outcome of his enterprise; he truly believes that he can convince the Supreme Council of the Irish Volunteers to abort the rebellion. Thus, the play closes on a positive note, with the police arriving to capture him although he thinks that they are Monteith and Bailey, finally come to rescue him so that he can complete his mission.

The second play on Casement to have already been produced is Peter Arnott's (2016) Shall Roger Casement Hang? This was premiered in May 2016, in Glasgow, 
in a production by the Tron Theatre Company, and was published the same year. Divided into twelve scenes the play is set during the three days of interrogation condensed to two in Arnott's version - undergone by Casement in Scotland Yard during the Easter holiday of 1916. Previous and subsequent events in Casement's life and career are interspersed in this central narrative in the form of short scenes which, presented in non-chronological order, serve to cast light on certain aspects of what has been or will be discussed in the interrogation room. These scenes include Casement's capture by a Royal Irish Constable on Banna Strand, and his subsequent confession to a priest in Tralee prison; the voice of young Elima making a statement to him about maltreatment in her African village in 1903 (drawn from the Enclosures of the Congo Report, edited by O'Síocháin and O'Sullivan); the voice of Captain Reginald Hall, Chief of Naval Intelligence at the Admiralty, reading excerpts from Casement's Black Diaries and, earlier, talking on the phone about the existence of these diaries which had just been found in Casement's London lodgings.

In Arnott's play, Captain Reginald Hall, described as an "Officer in the Royal Navy from Scotland" (2), is the only interlocutor to interrogate Casement. In fact, historical records show that a Superintendent of the Yard and a shorthand writer were also present; Hall himself was merely an assistant to Basil Thomson, who conducted the interrogation. Arnott elevates the Captain to the status of protagonist, who is respectful and even amiable with Casement in their first interview. He offers the prisoner every chance to avoid the threatened charge of high treason and he is ultimately convinced that Casement had returned on a peace mission "to call [the uprising] off..." (65). However, on the second day, after reading the damning diaries and learning that the rebellion had actually broken out in Dublin, he becomes aggressive. He abuses Casement verbally and they openly discuss the content of the Black Diaries and the diarist's sexual preferences. To the accusation that he is "not just a traitor to us" but also "a traitor to your sex, to nature and to God" (67), Casement answers that he "decided, years ago, to live as a homosexual man" just as he "decided to live as an Irishman" (72), and implies that Hall's behaviour denotes traces of homosexuality, typical of the "'real man' . .. whose reaction to his first arousal is to lash out at the object of his desire" (72). The enraged Captain loses control and slaps Casement repeatedly and furiously.

Despite the license taken in order to imbue the plot with the tone of an intimate psychological thriller, Arnott is quite faithful to Montgomery Hyde's account of the interrogation in the introduction to his book on Casement's trial. However, the Glaswegian playwright progressively alters the nature of the relationship between Casement and his interrogator in order to include aspects of Casement's life and career in Germany and South America, which do not feature in the interspersed scenes from Casement's past and future. In the last of these, in the closing moment of the play, Casement is in the Tower of London, "in the shadow of the scaffold that awaits him" (3), an image that has hovered over the stage throughout the play. As he awaits his trial Casement laments the destiny of "those fellows from the post office" (78), shot dead by British forces in 
Dublin, and paraphrases Patrick Pearse, one of the rebels executed, stating that, "while Ireland holds these graves ... Ireland will never be at peace" (78). At the very beginning of the play, Bernard Shaw had also echoed Pearse when he asks whether Roger Casement deserves to be executed. This is a reference to his letter entitled “Shall Roger Casement Hang?”, published in The Manchester Guardian, on 22 July 1916, and reprinted in the New York American, on 13 August, in which Shaw argues that Ireland already has enough heroes and martyrs. Casement will be added to their number if he is executed, and "if England has not by this time had enough of manufacturing those martyrs in fits of ill temper, then experience is thrown away on her" (4). In posing the very same question a century later, Peter Arnott once again spotlights Casement's legacy.

Fintan O'Toole's (2016) unpublished The Nightmare of Empire/The Dream of Europe is a very short monologue, which was read by Olwen Fouéré on 25 March 2016, as part of the programme "Imagining Home," at the National Concert Hall, in Dublin. It is in two parts. The first portrays Casement, apparently in a hotel room in Berlin, getting ready to board the submarine that will take him back to Ireland. In this cold bedroom, he ponders over his "feverish nationalism," refers to his Congo Report, and establishes an analogy between his mental condition and the rapid spinning of a car wheel with its rubber tyre. His mind wanders as he connects his past experiences in Africa with the contemporary world of the rubber industry. He feels that he carries the empire inside him and sometimes, "when I am really mad, I think that if they killed me, it would die with me" (5).

In the second part, entitled "The Fever (The Myth of Tantalus)," a now dead and feverish Casement expands his reasoning about the type of imperialism he understands to be still operating in the twenty-first-century world. The rubber industry has been replaced by technological giants, and it is now companies such as "Apple, Samsung, Sony" (6) which are exploiting African miners who, under inhuman conditions, have to extract valuable minerals, essential in mobile phones and laptops, including the mineral called Tantalum. Through Casement's words, O’Toole establishes a connection between the myth of Tantalus, as recorded by Ovid, and the consumerism of our times. The problem is that only a minority of the world's population have access to hi-tech products. The remainder of ordinary people, like Tantalus, are condemned merely to covet them. Meanwhile, African miners continue to be exploited in order to satisfy a handful of greedy modern imperialists. Due to the injustice resulting from this state of affairs, Casement's ghost cannot rest in peace, so he must wander the earth denouncing what is still wrong in human social, political and economic interactions.

\section{As Duas Mortes de Roger Casement - the Playwright's Perspective}

At first sight it may seem that As Duas Mortes de Roger Casement has much in common with the dramatisations summarised above, particularly in terms of its depiction of some characters and situations, and even of the structure of certain episodes. In fact, although my play script was based on the same bibliography of 
primary and secondary sources, I had no contact with any of the dramatic texts until I had finished my own work. That some of my choices coincide with those made by the above-mentioned dramatists is simply due to the fact that we have all sought inspiration in the same sources. One major difference between my own text and theirs derives from my intention of introducing Roger Casement to a Brazilian audience largely unaware of his life and career - despite the years he spent in the country. From the outset I wanted to write a "documentary play" with music, which would present both Casement's public trajectory and his private affairs. I kept as close as possible to the documents written by Casement or about him, whilst allowing myself the liberty to modify the sequence of events and the identity of certain characters. Sometimes multiple characters were condensed into one, and some circumstances were either altered or entirely invented.

After three years of research and the testing in rehearsal of different versions of the script, As Duas Mortes de Roger Casement premiered on 1 September 2016, at the Teatro Aliança Francesa, in São Paulo, where it ran for two months. A cast of eight (seven male and one female), along with an onstage pianist, performed the musical numbers composed by Alberto Heller and choreographed by Janette Santiago, and under my own direction they presented a narrative divided into two parts, denominated Side A and Side B. The two parts, separated by an interval, were designed so that Casement's public and private lives could be conveyed in two very distinct segments. Allusions to the Black Diaries are nuanced in Side A, in such a way that those unacquainted with their contents (virtually the entire Brazilian audience) form only an imprecise notion of what is implied. In my narrative this extends to Casement in his prison cell who, in accordance with historical sources, is vaguely aware that some compromising documents involving his name are circulating through the upper echelons of London society. In contrast, in the second part of the play, the focus is precisely on those diaries and the controversies surrounding them. Originally written in Portuguese, the final version of the play was eventually translated into English by myself and revised by Professor Peter James Harris, as part of the concluding activities of my postdoctorate at UNESP/São José do Rio Preto. The Portuguese script was published in June 2017, in Qorpus, the online journal of the Postgraduate Translation Studies programme of the Federal University of Santa Catarina, Brazil.

In the first part of the play, which is longer than the second, the aim was to portray Casement's public life chronologically, from his investigative missions as British Consul in Africa and South America to his subsequent involvement with the struggles for Irish Independence that resulted in his arrest, trial and execution. In a structure similar to that imagined by Mario Vargas Llosa (2010) in his novel The Dream of the Celt and the eponymous play by Alan Gilsenan (2016), I also visualised Casement in Pentonville prison waiting to be sentenced to death in 1916. However, in my version, the character referred to as the Sheriff is just a prison officer whose main function is to introduce the only person to visit Casement twice in his cell: his friend Alice Milligan, a Northern Irish writer and theatre practitioner who made sketches of him "in the court room 
during his trial" (Morris 283). In the course of her career, Milligan "developed a form of storytelling in which narrative was conveyed through a combination of staged pictures, ... live music and off-stage ... narration" (36). During these two fictional encounters at the prison, the character of Alice Milligan, inspired by the study made of her by Catherine Morris, encourages Casement to recollect some of his achievements - which are displayed in the form of tableaux vivants, music and narrations. She thus incorporates two functions at the same time: narrator of Casement's evolution towards becoming a revolutionary, and confidante. As a result, her role in the play is quite different from that of Gertrude Bannister, Casement's cousin who actually did visit him in prison - who is portrayed by Patrick Mason and Alan Gilsenan in their plays, and by Vargas Llosa in his novel. In the latter two cases Milligan is also a special visitor, but not the only one.

Alice Milligan defined herself as being "not so much a visionary as an interpreting intelligence" who foresaw Casement's trial and execution "as early as 1894 in automatic writings, visions and dreams" (Morris 51). Intending to lead the Brazilian audience to empathise with the protagonist, I emphasised, like Banville, Casement's movements in the Amazon region. His earlier interventions in Africa are mentioned in the lyrics of songs and some tableaux - as well as being part, in a different key, of a nightmare at the very beginning of the second part, called Intermezzo, in which Casement finds himself at Lake Mantumba taking statements from the natives, and feels as if he were one of the girls he interviewed there. In the real plane of his recollections, references to his activities in tropical forests are restricted to the Putumayo region - and summarised in three components: the testimony given by a condensed character named James Chase, a native of Barbados, who reveals the treatment inflicted on his countrymen and on the native Indians in the region dominated by the Peruvian Amazon Company; Casement's relationship with Juan Tizon, one of the Company's two main representatives, and his involvement with the members of the investigative Commission who came from London with him; and his final identification with Cacique (Chief) Katenere, who enables him "to see the truth: ... that [the Irish people] are like the Indians of Putumayo" - that their nations are both colonies "exploited by British laws and institutions" (Nunez 20).

When Casement returns to Britain from the Putumayo, he becomes a radical rebel, resigns from his post as a British consul and becomes totally committed to the Irish cause. Welcoming him once again to her "splendid vision," Milligan recalls Casement's involvement with the struggles in Ireland, his trip to Germany and his return to his homeland two years later in an attempt to stop the Rising. Like him, she was also involved in the struggle for Irish freedom. Milligan believed that her work with schools and amateur theatre groups could be used as a powerful tool to integrate localised political and religious visions in a kind of shared national democracy. Although she knew Casement, and worked closely with him, they were not such close friends as I portrayed them in my script. She wrote petitions to the British Home Office on his behalf, and never gave up her resistance in the name of an ideal Ireland up 
until her death at the age of eighty-seven in 1953; but historically she did not meet him many times, let alone in prison.

Her insertion into the plot in such an outstanding position was motivated, in the first place, by the fact that I wanted a female presence who might lend a graceful touch to a documentary format; and secondly, because none of the other women surrounding Casement, such as Alice Stopford Green, her cousin Gertrude Bannister or his sister Nina, appealed to me. On the one hand, there was not enough material about them; and on the other, they lacked the peculiarities of Milligan, who was an uncommon mixture of "political idealism and literary [and artistic] achievements" that were interlocking expressions of "a forthright and withal sensitive personality" (Morris 80 ). With her multiple role in reality - as a theatre practitioner, musician, poet, journalist and activist, as well as a kind benefactor who "spent considerable time caring for her English sister-inlaw" (63), after her brother's death in the war, her role as a narrator in the first part, and an understanding friend in the second not only served my purpose of including a metalinguistic element in a script containing many dramatic and epic features, but also helped to give coherence to the heterogeneous threads I was weaving into the fabric of the play as a whole.

In my narrative, after Casement has been caught at McKenna's Fort, Alice Milligan takes her seat in the court as a bystander of his trial, while he is first interrogated by Basil Thomson at Scotland Yard and then taken to Bow Street Police Court, in London, where he is judged, found guilty and sentenced to death. To achieve smooth movement, Casement's interrogation in the play is conducted only by Thomson; while Reginald Hall, the Admiralty Intelligence chief, who assisted him in his task, is excluded. For the same reason, I resolved not to include as characters Casement's companions on his submarine voyage back from Germany, Monteith and Bailey, nor most of the members of the Appeal Court bar. Towards the end of the first part of the play, in the Court of Criminal Appeal, in London, Sergeant Sullivan, Counsel for the prisoner, and the Attorney-General, Sir Frederick Smith, for the Crown, are briefly drawn into a ferocious argument about the indictment under which Casement was charged, and eventually the appeal is dismissed by the Lord Chief Justice. From this point on, in a sort of reverie, Casement learns that there will be no reprieve, meets Alice Milligan one last time; and, coming across Father Thomas Carey, one of the Irish priests "who were the Catholic prison chaplains and with whom [he] had been under instruction since his arrival in Pentonville" (Montgomery Hyde cxxxiv), he makes a final plea to be received into the Roman Catholic Church. The hangman then puts the noose around his neck and the first death of Roger Casement is enacted.

Casement's second death involves the moral questions raised by the Black Diaries, which started to circulate during his trial. Casement was sentenced to death not only because he committed the crime of high treason "by adhering to the King's enemies elsewhere than in the King's realm" (Singleton-Gates 465), in contravention of Edward III's Treason Act of 1351, but also because he allegedly had a "voracious appetite for young men" (Nunez 37). For his enemies, and for the 
enemies of the Irish cause, it was not "only necessary that Roger Casement died, but that he should die a dishonoured man" (Singleton-Gates 20). For that reason, the so-called "Black Diaries," a term coined by Singleton-Gates and Maurice Girodias in 1959, were used in order to alienate sympathy, and make a reprieve impossible. This set of three diaries and a cash-ledger for the years of 1903, 1910 and 1911, in which Casement allegedly recorded his numerous homosexual liaisons in different parts of the world, sometimes with underage boys, constitutes the subject matter of the second part of As Duas Mortes de Roger Casement.

In this second act, Casement's remains are being sent to Ireland from Pentonville to be reinterred at Glasnevin Cemetery, in Dublin, in a plot reserved for him by his sister some years previously. It is now February 1965 and his bones are being flown from RAF Northolt to Baldonnel military air base near Dublin. He will be received as a hero by high-ranking politicians and "the colossal figure of 665,000 people" (Dudgeon 612) on an extremely cold winter's day. When he awakes from his nightmare in the tropical forests, Casement finds himself inside the cargo hold of an aircraft in the presence of the ghosts of Alice Milligan and Dr Hawley Harvey Crippen. This American doctor, who had poisoned his wife in North London and "dismembered her body and buried parts of it in his cellar" (Reid 120), had attempted to escape "with his lover Ethel le Neve [disguised as a man], first to the Continent and then to Canada, but was arrested before he could land [there]" (120). He was then tried and, on 23 November 1910, he was hanged at Pentonville prison, and his body thrown, coffinless, into the same limepit where Casement's body would be placed six years later. Because of this peculiar and farcical detail, by the time Casement's remains were returned to Ireland and reburied "following a full state funeral, ... rumours circulated that Casement's and Crippen's remains had been confused" (Mitchell 373).

This premise of Casement's and Crippen's bones being mixed in the grave and their ghosts meeting inside an aircraft bound for Ireland was first dramatised by David Rudkin in his 1974 radio play, Cries from Roger Casement as his Bones are Brought to Dublin. However, in Rudkin's play, the brief isolated couple of scenes in which "these bones are personified and become characters" have the sole function of "adding a humorous, and at the same time ironic, tinge to the dialogue" (Bolfarine). The overall aim of Rudkin's play, based on historical documents, is to examine how the fragments of a divided identity could coexist in the same man, and how homosexuality played a crucial role "in his transformation into a nationalist" (Bolfarine). Although inspired by this situation as envisaged by Rudkin in his radio play, and by its humorous possibilities which I extended to the entire second part of my narrative, as a counterpoint to the more serious tone of Side A - , the primary function of Crippen in As Duas Mortes de Roger Casement extends beyond black humour. In my play he has the Black Diaries in his possession; he gradually reveals them to Casement and, like a kind of diabolical inquisitor, questions him about their authenticity. Having outlived both men for decades, Alice Milligan is partially aware of the controversies surrounding these diaries but, instead of counter-arguing or taking 
sides, she puts herself in the position of understanding friend. This eventually gives Casement the courage to acknowledge his sexual orientation, and to defy the reactionary Republicans and their patriarchal world.

Although I personally believe that the Black Diaries are genuine, the Casement character depicted in this section of the play is reluctant to respond to Alice's appeal. My intention was to maintain a certain aura of doubt as to whether the diaries were forged or not. To that end, Crippen frequently shows one or other of the diaries to his flight companions, and passages from them are enacted on the stage in scenes with an aura of cabaret - in which another actor, Casement's double, performs what he allegedly jotted down in these compromising documents. The Casement whose remains are being transferred to Dublin is apparently not acquainted with the Diaries and their contents, and is transformed into a mere spectator of what is performed on the stage. This is when Alice breaks the barrier of time and place, and invites two contenders to enact in a boxing bout, in an unspecified future, the controversy of the Black Diaries. This scene is actually a summary of arguments defended by scholars such as Angus Mitchell, Séamas Ó Síocháin, Jeffrey Dudgeon and Roger Sawyer, and it leads Casement to vaguely assume his homosexuality, through a poem he wrote as a young man, when he states to Alice that the love he is seeking is sanctioned by God. At the end of the play, as a result of this confession, he recites, in the middle of a song, some lines from the diaries referring to Millar Gordon, apparently "the only partner whose social background had anything in common with Casement" (Sawyer 20), and for whom he bought a motorbike on 1 June 1911 which he sent to Belfast as a gift.

Finally, the aircraft lands; and there is no time left for further discussion. Casement's coffin is draped in the Irish flag, but, in a final gesture, Alice undresses him, and cleans his body in a kind of purification ritual that concludes with the image of a man totally exposed, open to whatever evaluation people may make of his actions as a public figure, along with the alleged reprehensible behaviour of his private life. Should this blemish diminish his role as one of the greatest Irish nationalist heroes of his time? Leaving the answer to the audience, Alice invites Casement to repose, while she sings a popular Irish lullaby which promises that "angels are coming to watch over [his] sleep ... and rock [him] asleep" (Nunez 44). Nonetheless, Casement's soul will hardly rest in peace in Glasnevin Cemetery. His wish was to be buried in the old churchyard at Murlough Bay, in Northern Ireland. However, Northern Ireland is still part of the United Kingdom, where his remains are unwelcome. Casement's ghost is therefore likely to continue haunting the public life of Ireland until the country becomes a unified nation and his remains can be taken to the place in which he chose to spend eternity.

\section{Thanks}

This project was made possible by the support of a CAPES grant and the invaluable assistance of the literary director and producer of the theatre company, Cia Ludens, Dr Beatriz Kopschitz Bastos. 


\section{References}

Arnott, Peter. Shall Roger Casement Hang? Vagabond Voices, 2016.

Banville, John. "Casement." Breac: A Digital Journal of Irish Studies, April 2016, http:// breac.nd.edu/.

Bolfarine, Mariana. "From Fragments to a Whole: Homosexuality and Partition in Cries from Casement as his Bones are Brought to Dublin." Breac: A Digital Journal of Irish Studies, April 2016, http://breac.nd.edu/.

Bolfarine, Mariana. Between "Angels and Demons": Trauma in Fictional Representations of Roger Casement. Humanitas, 2018.

Clifford, Brendan, editor. Roger Casement: The Crime Against Europe with The Crime Against Ireland, and other writings. Athol Books, 2003.

Conrad, Joseph. Heart of Darkness. Penguin, 1989.

Curry, Charles. Sir Roger Casement's Diaries - His Mission in Germany and the Findlay Affair. Arche, 1922.

Dudgeon, Jeffrey. Roger Casement: The Black Diaries with a Study of His Background, Sexuality, and Irish Political Life. Belfast Press, 2002.

Dudgeon, Jeffrey, editor. Roger Casement's German Diary 1914-1916. Belfast Press, 2016.

Fanning, Arnold Thomas. MacKenna's Fort. Unpublished, 2016.

Gilsenan, Alan. The Dream of the Celt. Unpublished, 2016.

Harris, Peter James. "From Putumayo to Connemara: Roger Casement's Amazon Voyage of Discovery." ABEI Journal - The Brazilian Journal of Irish Studies, vol. 4, 2002, pp. 131-8.

Inglis, Brian. Roger Casement. Penguin, 2002.

MacColl, René. Roger Casement: A New Judgement. Hamish Hamilton, 1956.

Mackey, H. O., editor. The Crime Against Europe: The Writings and Poetry of Roger Casement. Athol Books, 2003.

McDiarmid, Lucy. "The Posthumous Life of Roger Casement." Gender and Sexuality in Modern Ireland. Edited by Anthony Bradley and Maryann Gialanella Valiulis. U of Massachusetts P, 1997.

Mason, Patrick. "The Dreaming of Roger Casement." Breac: A Digital Journal of Irish Studies, April 2016, http://breac.nd.edu/.

Mitchell, Angus, editor. The Amazon Journal of Roger Casement. Lilliput Press, 1997.

Mitchell, Angus, editor. Roger Casement's Heart of Darkness: the 1911 Documents. Irish Manuscript Commission, 2003.

Mitchell, Angus. 16 Lives: Roger Casement. The O’Brien Press, 2013.

Montgomery Hyde, Harford, editor. The Trial of Sir Roger Casement. W. Hodge, 1973.

Morris, Catherine. Alice Milligan and the Irish Cultural Revival. Four Courts Press, 2013.

Murphy, Colin, and Ronan Kelly. Roger Casement's 'Apocalypse Now'. Unpublished. 2016.

Nunez, Domingos. “As Duas Mortes de Roger Casement." Qorpus, June 2017, http:// qorpus.paginas.ufsc.br/.

Nunez, Domingos, The Two Deaths of Roger Casement. Unpublished, 2017. 
O'Donnell, Mike. Roger Casement's 1916. Kindle Edition, 11 April 2013.

Ó Síocháin, Séamas, Roger Casement: Imperialist, Rebel, Revolutionary. Lilliput Press, 2008.

Ó Síocháin, Séamas, and Michael O'Sullivan, editors. The Eyes of Another Race: Roger Casement's Congo Report and 1903 Diary. UCD Press, 2004.

O'Toole, Fintan. Casement: The Myth of Tantalus. Unpublished, 2016.

Reid, B. L. The Lives of Roger Casement. Yale UP, 1976.

Rudkin, David. Cries from Casement as his Bones are Brought to Dublin. BBC, 1974.

Sawyer, Roger. The Flawed Hero. Routledge, 1984.

Sawyer, Roger, editor. Roger Casement's Diaries, 1910: The Black and the White. Pimlico, 1997.

Singleton-Gates, Peter, and Maurice Girodias. The Black Diaries: An account of Roger Casement's life and times, with a collection of his diaries and public writing. Sidgwick and Jackson, 1959.

Toíbín, Colm. "A Whale of a Time." London Review of Books, vol. 19, no. 19, October 1997, pp. 24-27.

Vargas Llosa, Mario. The Dream of the Celt. Translated by Edith Grossman. Picador, 2010.

Recebido em: 01/10/2019

Aceito em: 26/11/2019 